\title{
The Role of Salt Bridge Formation in Glucagon: An Experimental and Theoretical Study of Glucagon Analogs and Peptide Fragments of Glucagon
}

\author{
Anne-Marie Sapse, ${ }^{1,3}$ Robert Rothchild, ${ }^{1}$ Duli C. Jain, ${ }^{2}$ and Cecilia G. Unson ${ }^{3}$ \\ ${ }^{1}$ John Jay College and Graduate School, City University of New York \\ ${ }^{2}$ York College, City University of New York \\ ${ }^{3}$ The Rockefeller University, New York, New York, USA \\ Accepted March 26, 2002
}

\begin{abstract}
Background: Glucagon is a 29-residue peptide produced in the $\alpha$ cells of the pancreas that interacts with hepatic receptors to stimulate glucose production and release, via a cAMP-mediated pathway. Type 2 diabetes patients may have an excess of glucagon and, as such, glucagon antagonists might serve as diabetes drugs. The antagonists that bind to the glucagon receptor but do not exhibit activity could be analogs of glucagon. The presence of salt bridges between some residues of glucagons (such as aspartic acid) and others (such as lysine) might influence both the binding to the receptor and the activity.

Materials and Methods: Experimental-The solid phase method with 4-methylbenzilhydrilamine resin (p-MBHA resin) was used for the synthesis of glucagon analogs. Rat liver membranes were prepared from male Sprague-Dawley rats by the Neville procedure. The receptor binding essay was performed in $1 \%$ BSA, $1 \mathrm{mM}$ dithiothreitol, $25 \mathrm{mM}$ Tris- $\mathrm{HCl}$ buffer, $\mathrm{pH}$ 7.2. Adenyl cyclase activity was measured in an assay medium containing $1 \%$ serum albumin, $25 \mathrm{mM} \mathrm{MgCl} 2,2 \mathrm{mM}$ dithiothreitol, $0.025 \mathrm{mM}$ GTP, $5 \mathrm{mM}$ ATP, $0.9 \mathrm{mM}$ theophylline , $17.2 \mathrm{mM}$ creatine phosphate,
\end{abstract}

and $1 \mathrm{mg} / \mathrm{ml}$ creatine phosphokinase. Theoretical-Quantum chemical calculations using the Titan program with the 6-31G* basis set were performed to calculate the binding energies of salt bridges between aspartic or glutamic acids and lysine. The relative stability of cyclic conformations of glucagon segments versus the extended segments was determined.

Results: It was found that the cyclic Glu9-Lys12 amide compound displayed a 20 -fold decrease in binding affinity. DesHisl cyclic compounds Glu20-Lys24 amide and DesHis IGlu9 Glu20-Lys24 amide behave as glucagon antagonists. The calculations show that cyclic conformations of tetrapeptidic and pentapeptidic segments of glucagon are more stable than the extended species.

Conclusions: The biological data and the theoretical calculations show that an intramolecular salt bridge might impart stability to some glucagon antagonists and, when situated at the C-terminus of glucagon, might facilitate induction of an $\alpha$-helix upon initial hormone association with the membrane bilayer. These findings might be a useful tool for the design of new glucagon antagonists.

\section{Introduction}

Glucagon is a 29-residue peptide hormone secreted by pancreatic A cells responsible together with insulin for maintaining normal levels of glucose critical to the survival of an organism. The driving force for continued efforts to study glucagon lies primarily in the still unresolved problem of diabetes mellitus. There is persuasive evidence that the major metabolic complications of diabetes, hyperglycemia and ketoacidosis, are often accompanied by an abnormal increase in the level of plasma glucagon relative to insulin $(1,2)$. Glucagon activity is mediated by the glucagon receptor, a member of family $B$ receptors within the superfamily of $G$ protein-coupled receptors that includes receptors for many important

Correspondence and reprint requests should be addressed to: Dr. Anne-Marie Sapse, John Jay College and Graduate School, City University of New York, New York, New York, 10019. Phone: 212-237-8949; fax 212-935-3594; e mail: acransg6@aol.com. peptide hormones $(3,4)$. The biological effects of glucagon are initiated by high-affinity binding to its membrane-bound receptor, the necessary first step in glucagon action. Upon glucagon binding, the extracellular signal is transduced across the cell membrane to activate adenylyl cyclase via the heterotrimeric $G$ protein $G_{s}$ resulting in an increase in cAMP, which mediates most of glucagon's cellular effects. Precise and efficient signaling that ultimately results in glucose production requires specific binding of glucagon to its cell surface receptors. Thus, structural information about the peptide ligand that influences receptor binding affinity is central to the design of antagonists of glucagon. An analog of glucagon that binds to the receptor but does not activate adenylyl cyclase is considered an antagonist. Thus, a good antagonist will compete for glucagon binding and inhibit adenylyl cyclase. A structural analog of glucagon that inhibits glucagon action by competing effectively for receptor binding sites is a reasonable target for drug design as an alternative or 
adjunct to insulin therapy in the management of diabetic complications.

Numerous structure-function studies of glucagon have singled out specific active site residues responsible for either high-affinity binding or activation and afforded some insight into its mechanism of action. We have demonstrated that the negatively charged side chain of aspartic acid residues at positions 9,15 , and 21 play important roles in either the binding or activity function of the hormone $(5,6)$. The $\mathrm{N}$-terminal histidine, which is strictly conserved within the family, furnishes determinants of both binding and activity of the hormone $(7,8)$. The positively charged groups at positions 12,17 , and 18 contribute to receptor recognition and ensure maximum biological potency $(9,10)$.

The molecular basis for the interaction of glucagon with the glucagon receptor remains to be elucidated. It is widely accepted that the glucagon binding site resides in the extracellular domain of the receptor, which consists of the long amino terminal tail and three extracellular loops that connect the transmembrane helices $(11,12)$. In the presence of its receptor, glucagon changes its conformation to the activated form. It had been suggested that intramolecular salt bridges within the glucagon molecule stabilize the active conformation and allow formation of a more compact folded structure that facilitates hormone access to its binding pocket within the closely packed extracellular region of the receptor. There are amino acid residues in glucagon that could potentially form salt bridges. Indeed, the X-ray crystal structure of $\left[\mathrm{Lys}^{17,18}, \mathrm{Glu}^{21}\right]$ glucagon amide revealed that the ability to form a salt bridge between Lys ${ }^{18}$ and $\mathrm{Glu}^{21}$ is likely responsible for the analog's enhanced binding and superagonist activity $(10,13)$.

To examine the feasibility of salt bridge formation in glucagon and its significance to glucagoninduced receptor binding and activation, we synthesized four glucagon analogs (Table 1, 2-5) with an internal lactam. Lactam cyclization resulting from a covalently bonded side chain salt bridge should stabilize secondary structures if they are present in the peptide. Amide bond formation was allowed to occur between $\mathrm{Glu}^{2}$ and Lys ${ }^{5}$, analog 2, Glu $^{9}$ and Lys ${ }^{12}$, analogs 3 and 4, and $\mathrm{Glu}^{20}$ and Lys $^{24}$, analog 5, in the corresponding glucagon analogs. The binding and activity parameters of the resulting lactam-containing glucagon analogs were compared to acyclic counterparts to determine whether formation of a cyclic structure was favorable at those positions.

In addition, the present work applied theoretical methods to study the energetics of salt bridge formation in glucagon by using the following as model structures. The complex formed by free aspartic acid and lysine residues was analyzed in two conformations. The first, featuring the formation of a salt bridge with the hydrogen of the aspartic acid carboxyl directed toward the lone pair of electrons on the lysine $\epsilon$-amino nitrogen (Fig. 1A);

Table 1. Pharmacological parameters of cyclic analogues of glucagon

\begin{tabular}{|c|c|c|c|c|c|}
\hline \multirow[b]{2}{*}{ Glucagon and Analogues } & \multicolumn{2}{|c|}{$\begin{array}{c}\text { Receptor Binding } \\
\text { Activity }\end{array}$} & \multicolumn{3}{|c|}{ Adenylyl Cyclase } \\
\hline & $\begin{array}{c}\text { Relative } \\
\text { Affinity }^{a}, \\
\qquad \%)\end{array}$ & $\begin{array}{c}\text { Fold } \\
\text { Decrease }\end{array}$ & $\begin{array}{c}\text { Relative } \\
\text { Potencyb } \\
(\%)\end{array}$ & $\begin{array}{c}\text { Maximum } \\
\text { Activity }^{c} \\
(\%)\end{array}$ & $\begin{array}{l}\mathbf{p A}_{2}{ }^{\mathbf{d}} \\
\text { Value }\end{array}$ \\
\hline 1A Glucagon & 100 & & 100 & 100 & - \\
\hline 1B Glucagon amide & 100 & & 15 & 100 & - \\
\hline 1C DesHis ${ }^{1}$ glucagon & 8 & 12.5 & 0.1 & 36 & - \\
\hline 1D DesHis ${ }^{1}$ glucagon amide & 63 & 1.6 & 0.16 & 44 & - \\
\hline 2 Cyclic $\left[G^{2}{ }^{2}\right.$ Lys $\left.^{5}\right]$-amide & 0.41 & 244 & 0.58 & 100 & \\
\hline 3 Cyclic $\left[G^{\prime}{ }^{9}\right.$ Lys $\left.^{12}\right]$-amide & 4.8 & 21 & 0.126 & 18 & - \\
\hline 4 DesHis $^{1}$ cyclic $\left[\right.$ Glu $^{9}$ Lys $\left.^{12}\right]$-amide & 12.6 & 8 & $<0.00013$ & - & 6.9 \\
\hline 5 DesHis $^{1}$ Glu $^{9}$ cyclic $\left[\right.$ Glu $^{20}$ Lys $^{24}$ ]-amide & 19.1 & 5.3 & $<0.003$ & - & 6.8 \\
\hline \multicolumn{6}{|c|}{$\begin{array}{l}\text { a The ratio of unlabeled glucagon concentration required to displace } 50 \% \text { of receptor-bound }\left[{ }^{125} \mathrm{I}\right] \text {-glucagon, } \mathrm{IC}_{50} \text {, to the concentratio } \\
\text { required for analogues of glucagon } \times 100 \text {. } \\
{ }^{\mathrm{b}} \text { The ratio of glucagon concentration at } 50 \% \text { stimulation }\left(\mathrm{EC}_{50}\right) \text { of natural glucagon to that of glucagon analogue } \times 100 \text {. } \\
{ }^{\mathrm{c}} \text { The ratio of maximum response of glucagon analogue to that of natural glucagon } \times 100 \text {. } \\
{ }_{\mathrm{d}} \mathrm{pA}_{2} \text { value is the negative logarithm of the concentration of inhibitor that reduces the response to } 1 \text { unit of agonist to the response } \\
\text { obtained from } 0.5 \text { unit of agonist. }\end{array}$} \\
\hline
\end{tabular}




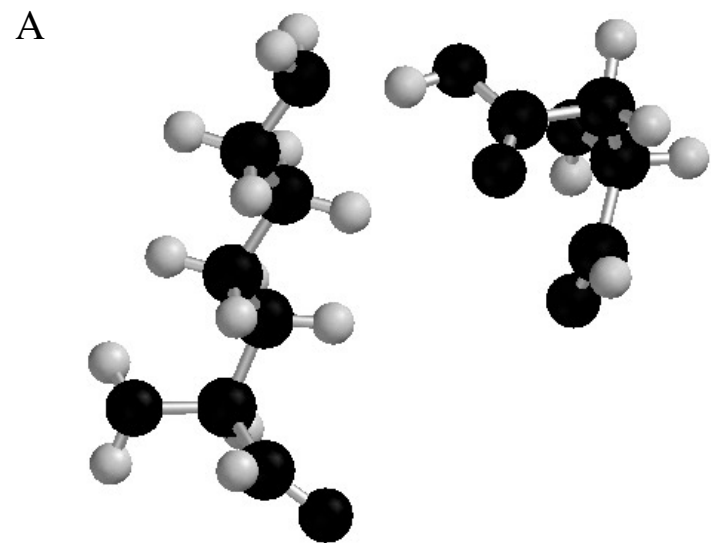

B

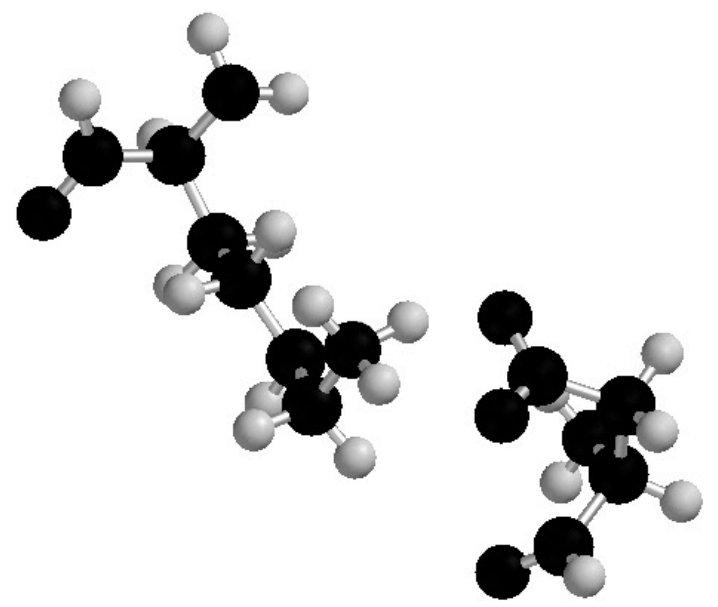

Fig. 1. (A) The complex formed by aspartic acid and lysine, featuring a hydrogen bond between the $\beta$-carboxyl hydrogen of aspartic acid and the lone pair of electrons on the $\varepsilon$-amino group of lysine. (B) The complex formed by the aspartate anion and the lysine cation, featuring hydrogen bonds between two hydrogens of the $\varepsilon$-amino group of lysine and the oxygens of the aspartate $\beta$-carboxylate group.

and the second, the formation of a salt bridge with the hydrogens of the nitrogen on lysine interacting with the carboxylate oxygens on aspartic acid. The latter model structure is a zwitterion (Fig. 1B). Identical calculations were performed on the same set of complexes formed by free lysine with a glutamic acid (Fig. 2A and B).

The energetics of intramolecular salt bridge formation were analyzed in three peptide models based on the glucagon sequence. First, a heptapeptide, Thr $^{7}-$ Ser $^{8}$-Asp ${ }^{9}-$ Tyr $^{10}{ }^{10}$ Ser $^{11}$-Lys ${ }^{12}-$ Tyr $^{13}$, represented residues 7-13 of glucagon. Several conformers of the peptide were studied with or without intramolecular salt bridge formation between Asp ${ }^{9}$ and Lys ${ }^{12}$ (Fig. 3). Second, a tetrapeptide, Asp ${ }^{9}$ Tyr $^{10}-$ Ser $^{11}$ Lys $^{12}$, represented residues 9-12 of glucagon. Several conformers with or without the salt bridge between Asp $^{9}$ and Lys ${ }^{12}$ were analyzed (Fig. 4). A glucagon analog with an amide bond between an Asp $^{9}$ and Lys ${ }^{12}$ has been synthesized (14). And third, a pentapeptide, Glu ${ }^{20}-\mathrm{Asp}^{21}-\mathrm{Phe}^{22}-\mathrm{Val}^{23}-\mathrm{Lys}^{24}$,
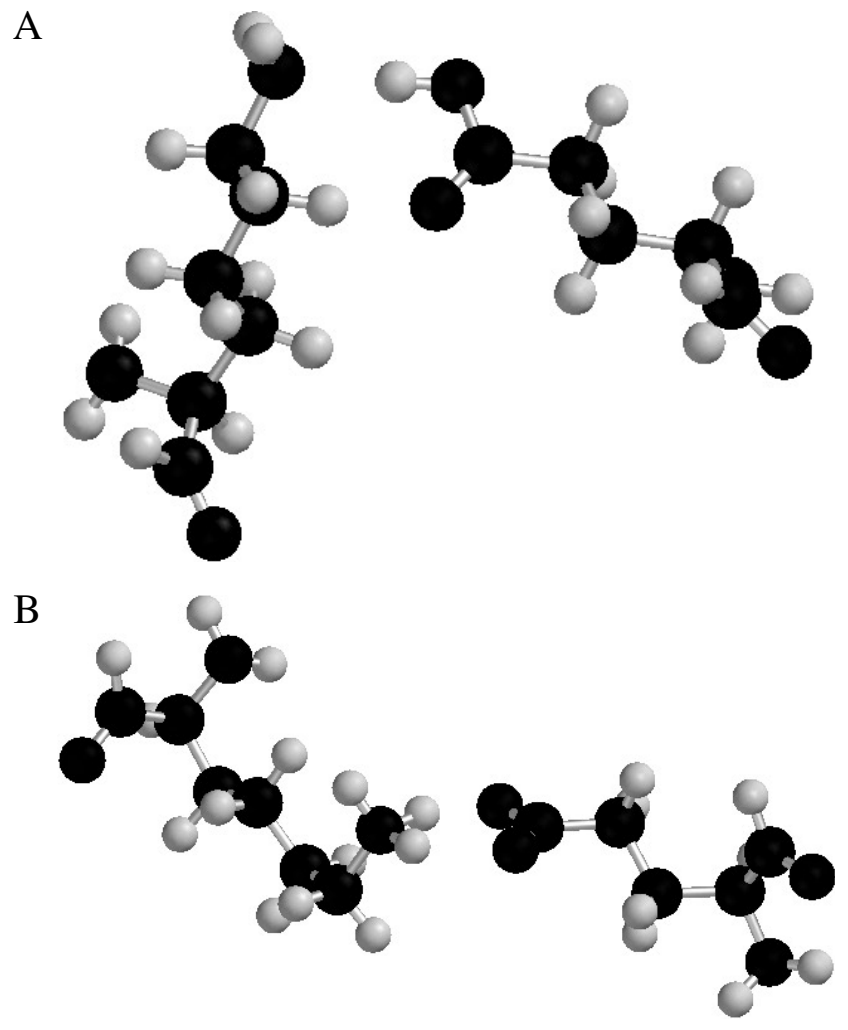

Fig. 2. (A) The complex formed by glutamic acid and lysine, featuring a hydrogen bond between the $\gamma$-carboxyl hydrogen of glutamic acid and the lone pair of electrons on the $\varepsilon$-amino group of lysine. (B) The complex formed by the glutamate anion and the lysine cation, featuring hydrogen bonds between two hydrogens of the $\varepsilon$-amino group of lysine and the oxygens of the glutamate $\gamma$-carboxylate group.

represented residues 20-24 of a glucagon analog synthesized with an amide bond between the $\gamma$-COOH of $\mathrm{Glu}^{20}$ and the $\varepsilon-\mathrm{NH}_{2}$ of Lys ${ }^{24}$.

\section{Methods}

Materials

tert-Butyloxycarbony (Boc)-protected amino acids were from Peptide Institute, Inc. (Osaka, Japan); 4-methylbenzlyhydrylamine resin (p-MBHA resin, $0.3 \mathrm{mmol} / \mathrm{g}$ ) and benzotriazolyloxytris[dimethylamino]-phosphonium hexafluorophosphate (BOP) from Peptides International (Louisville, KY, USA); $\mathrm{N}^{1}$-hydroxybenzotriazole (HOBt) and $\mathrm{N}, \mathrm{N}^{\prime}$-dicyclohexylcarbodiimide, from Fluka (Milwaukee, WI, USA); diisopropylethylamine and trifluoroacetic acid (TFA) from Aldrich (Milwaukee, WI, USA); acetonitrile, dimethylformamide and dichloromethane from Fisher Scientific (Fair Lawn, NJ, USA); ATP, GTP, creatine phosphate, and creatine phosphokinase, from Sigma Chemical Co. (St. Louis, MO, USA); monoiodinated ${ }^{125}$ I-glucagon from NEN Dupont (Boston, MA, USA); and the cAMP assay kit containing $\left[8-{ }^{3} \mathrm{H}\right] \mathrm{cAMP}$ was obtained from Amersham (Piscataway, NJ, USA). 


\section{Synthesis and Purification of Glucagon Analogs}

Glucagon analogs were synthesized by the solid phase method with p-MBHA resin on an Applied Biosystems $430 \mathrm{~A}$ peptide synthesizer using procedures developed for the synthesis of natural glucagons (15). All amino acids were coupled as their $\mathbf{N}^{\alpha}$-Boc derivatives. Standard protocol for double couplings with preformed symmetric anhydrides in dimethylformamide was used, except for arginine, asparagine, and glutamine, which were coupled as $\mathrm{N}^{1}$-hydroxybenzotraizole esters. Aspartic acid and glutamic acids to be cyclized were coupled as $\mathrm{N}^{\alpha}$-Boc-Asp$\left(\beta\right.$-Ofm) and $\mathrm{N}^{\alpha}$-Boc-Glu-( $\gamma$-Ofm), respectively. Lysine to be cyclized was coupled as $\mathrm{N}^{\alpha}$-Boc-Lys $\left(\mathrm{N}^{\varepsilon}\right.$-Fmoc). After removing the side chain $\mathrm{Fm}$ and Fmoc protecting groups of aspartic and lysine derivatives with $20 \%$ piperidine for $40 \mathrm{~min}$, the peptides were cyclized on the resin using three equivalents of

A

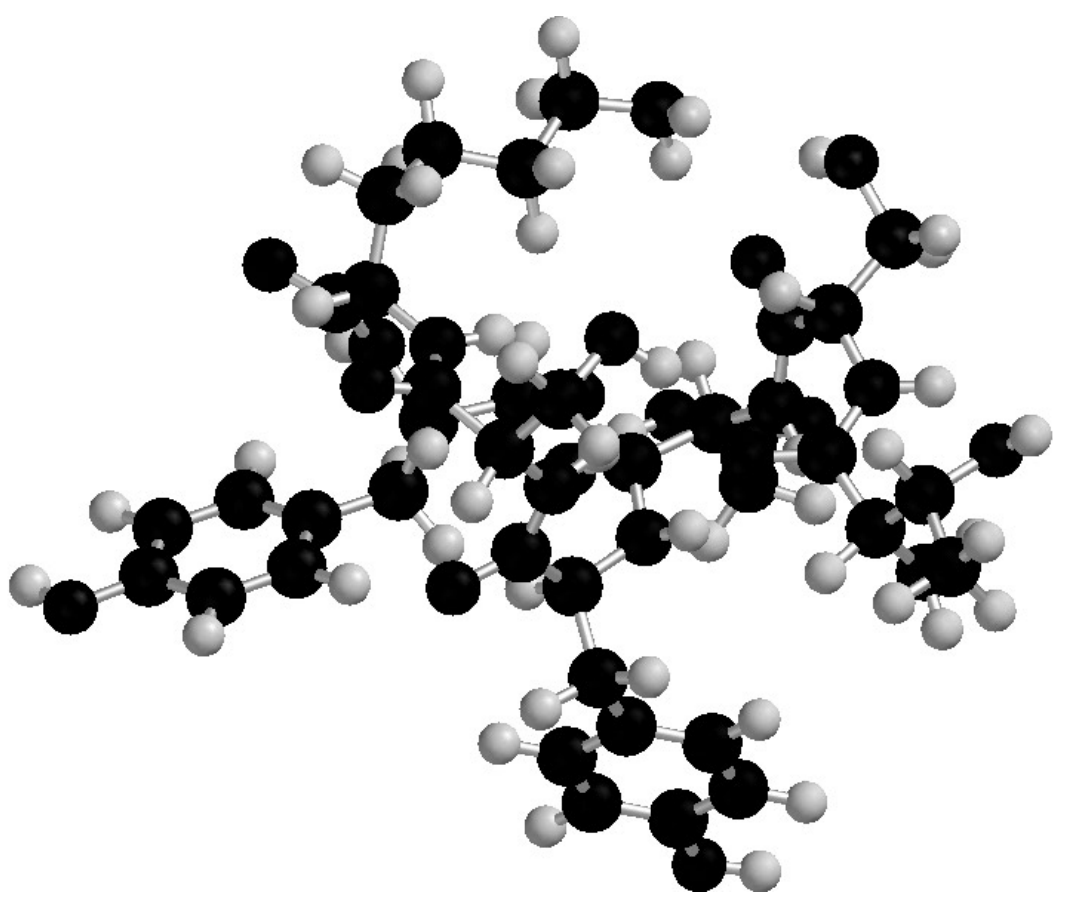

B

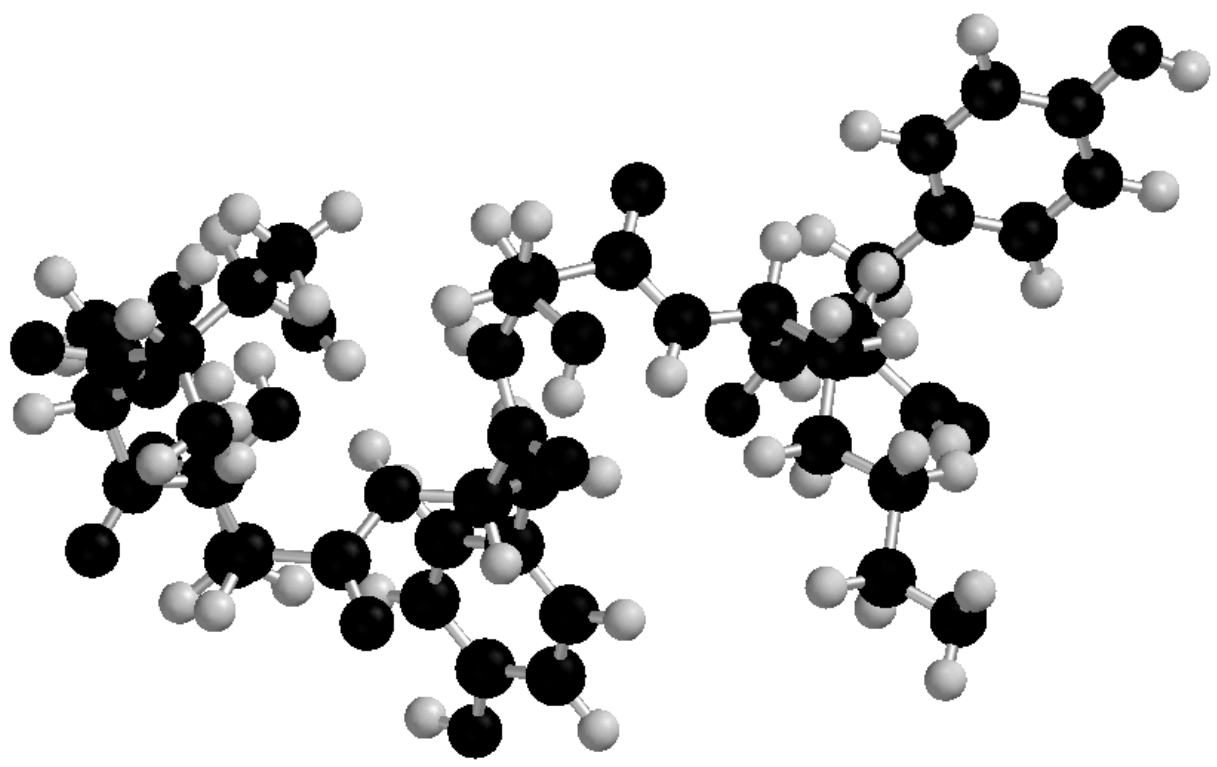

Fig. 3. (A) A conformation of a heptapeptide fragment derived from glucagon representing residues 7-13: Thr $^{7}-$ Ser $^{8}$-Asp 9 Tyr $^{10}-$ Ser $^{11}-$ Lys $^{12}-$ Tyr $^{13}$, featuring a hydrogen bond between the $\varepsilon$-amino group of lysine and the $\beta$-carboxyl group of Asp'. (B) An extended conformation of the heptapeptide in Figure 3A. (C) A coiled conformation of the heptapeptide in Figure 3A.

(D) Another extended conformation of the heptapeptide in Figure 3A, different from the conformation in Figure 3B. 


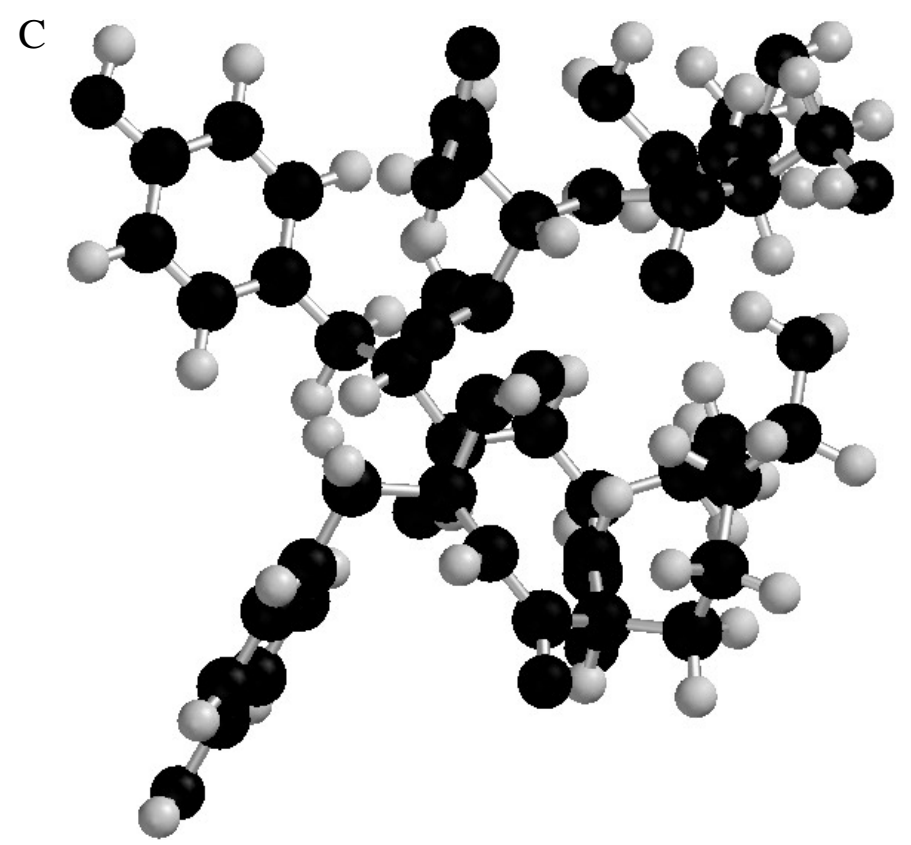

D

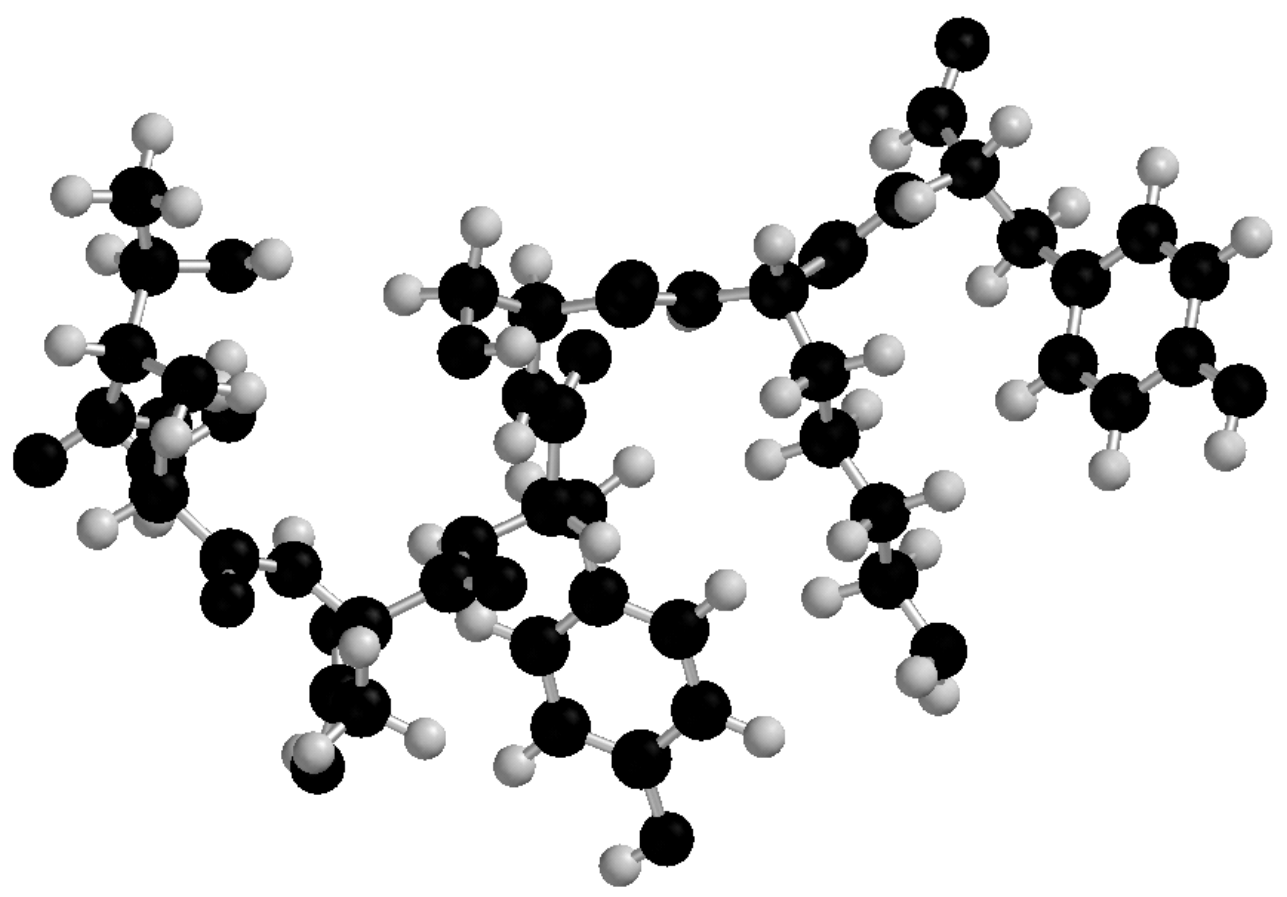

Fig. 3. (continued)

benzotriazolyloxytris[dimethylamino]-phosphonium hexafluorophosphate. The protected peptide resins were cleaved by the low-high HF procedure (16) and the crude peptides were extracted with $10 \%$ glacial acetic and purified as described previously (17). Purity of the peptide derivatives was verified to be greater than $95 \%$ by analytical HPLC on octadecylsilica (Vydac C18, Separations Group, Hesperia, CA, USA) applying a gradient of $25-45 \%$ acetonitrile in $0.05 \%$ aqueous TFA over $20 \mathrm{~min}$. Amino acid analysis yielded amino acid compositions consistent with theory. Mass spectral analysis using the electrospray method determined the $(\mathrm{M}+\mathrm{H})+$ peak to be within \pm 0.3 da of theory.

\section{Receptor Binding}

Rat liver membranes were prepared from male Sprague-Dawley rats (Charles River Laboratories) by the Neville procedure, resuspended in $\mathrm{NaHCO}_{3}$, and stored as aliquots under liquid nitrogen until use (18). Protein was determined by a modified Lowry method (19). The receptor binding assay 

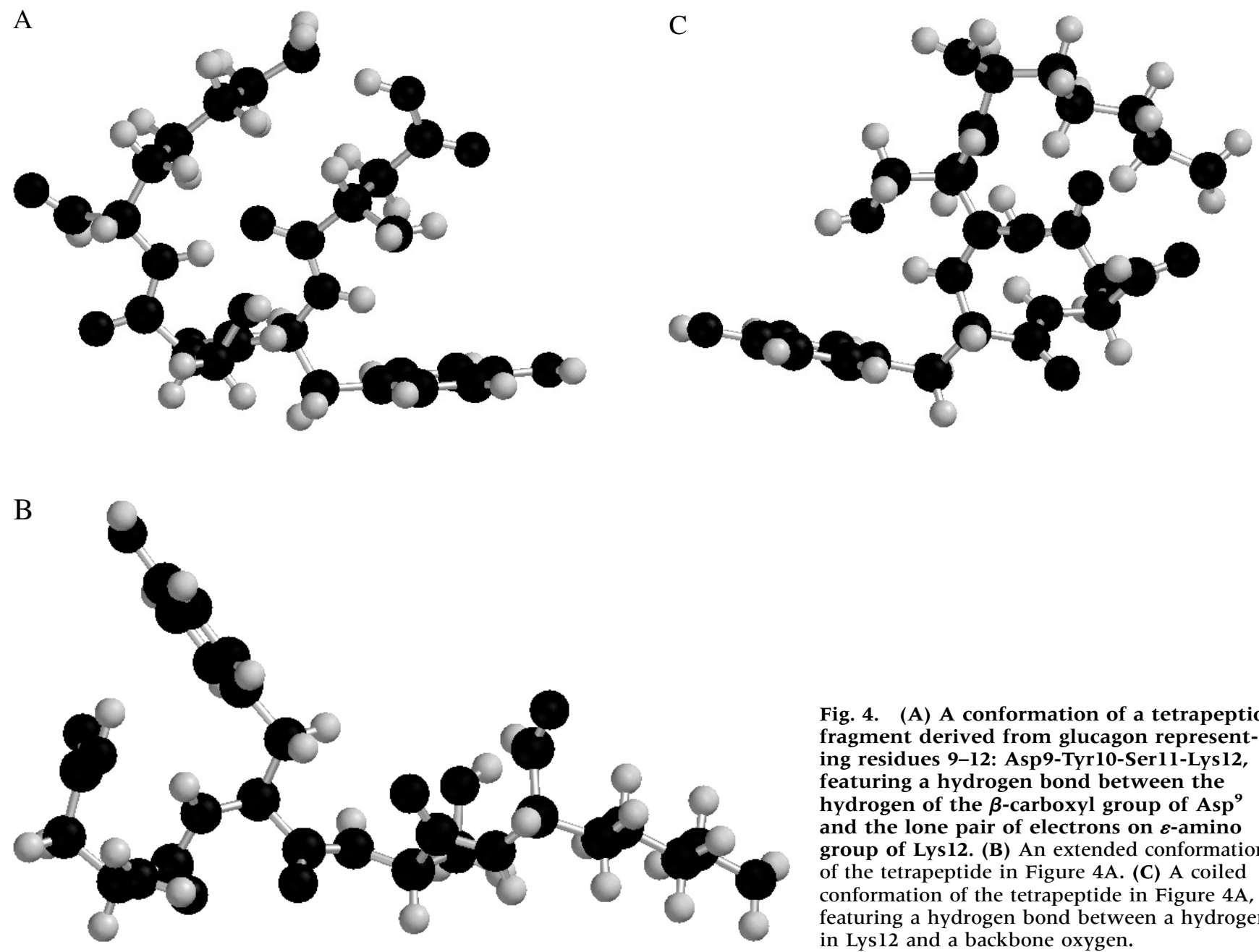

Fig. 4. (A) A conformation of a tetrapeptide fragment derived from glucagon representing residues 9-12: Asp9-Tyr10-Ser11-Lys12, featuring a hydrogen bond between the hydrogen of the $\beta$-carboxyl group of Asp' and the lone pair of electrons on $\varepsilon$-amino group of Lys 12. (B) An extended conformation of the tetrapeptide in Figure 4A. (C) A coiled conformation of the tetrapeptide in Figure 4A, featuring a hydrogen bond between a hydrogen in Lys 12 and a backbone oxygen.

was performed in $1 \%$ BSA, 1 mM dithiothreitol, and $25 \mathrm{mM}$ Tris-HCl buffer, pH 7.2 (20). The amount of radioiodinated glucagon displaced from receptor sites by increasing concentrations of antagonist was measured. Binding affinity was expressed as the ratio of the concentration of natural glucagon to that of the antagonist required to displace $50 \%$ of receptor-bound labeled glucagon multiplied by 100 .

\section{Adenylyl Cyclase Activity}

Adenylyl cyclase activity was measured in an assay medium containing $1 \% \mathrm{BSA}, 25 \mathrm{mM} \mathrm{MgCl}_{2}, 2 \mathrm{mM}$ dithiothreitol, $0.025 \mathrm{mM}$ GTP, $5 \mathrm{mM}$ ATP, $0.9 \mathrm{mM}$ theophylline, $17.2 \mathrm{mM}$ creatine phosphate, and $1 \mathrm{mg} / \mathrm{ml}$ creatine phosphokinase (21). The cAMP released was determined with a commercial kit from Amersham in which unlabeled cAMP was allowed to compete with $\left[8-{ }^{3} \mathrm{H}\right]$ cAMP for a high-affinity cAMP-binding protein. Data for stimulation of adenylyl cyclase are expressed as picomoles of cAMP produced per milligram of protein per minute and plotted against the logarithm of peptide concentration. Relative activity is a measure of the potency of the analog in the adenylyl cyclase assay and is expressed as the ratio $(\times 100)$ of the concentration of glucagon to that of the analog required to give half the maximum response of analog. This method of comparison was arbitrarily selected because the shapes of the activity response curves of natural glucagon and the analogs are not always parallel, especially in the case of partial agonists.

Inhibition of adenylyl cyclase was determined using the same procedure above except that increasing concentrations of peptide antagonist were allowed to compete with a constant concentration of natural glucagon. The ratio of the concentration of antagonist to agonist when the response is reduced to $50 \%$ of the response to glucagon in the absence of antagonist is the inhibition index $\left(I / A_{50}\right)$. The pA2 value, calculated also from the dose-response curve, is the negative logarithm of the concentration of antagonist that reduces the response to 1 unit of agonist to the response obtained from 0.5 unit of agonist (22).

\section{Theoretical Calculations}

The Asp/Lys and Glu/Lys ion pairing complexes were investigated with ab initio calculations, using the 
Titan computer program, version 1.05 (Wavefunction, Inc., Irvine, CA, USA). The basis set used is $6-31 \mathrm{G}^{*}$, at Hartree-Fock level. The $6-31 G^{*}$ basis set consists of one Slater orbital used for the description of the core electrons and expanded in a series of six gaussians, with the valence electrons described by two Slater orbitals each, one expanded in a series of three gaussians and the other approximated by one gaussian. In addition, $\mathrm{d}$ orbitals are set on nonhydrogen atoms. The geometries of the complexes are optimized and the results are shown in Table 2 . Scheme 1 shows the numbering of the atoms. The optimized complexes are shown in Figures 1 and 2 . The heptapeptide segment Thr-Ser-Asp-Tyr-Ser-Lys-Tyr (Fig. 3), which represents the 7-13 fragment of glucagon, has been investigated with the semi-empirical method AMI. Four different initial conformations were optimized and the resulting structures are shown in Figure 3. The Titan program was used. The tetrapeptide Asp-Tyr-Ser-Lys (Fig. 4), representing residues 9-12 of glucagon, was investigated with ab initio methods, using the 3-21G basis set, which uses one Slater orbital to the description of core electrons, expanded in a series of three gaussians. The valence electrons are described by two Slater orbitals, one expanded in a series of two gaussians, the other approximated by one gaussian. Geometry optimization was performed on three initial conformations and the results are shown in Figure 4. For all the structures considered, solvation energies were obtained using the SM5.4 model (23). In addition, the single-point energies of the tetrapeptides were also calculated with the $6-31 G^{*}$ basis set, using the 3-21G obtained geometries. Table 3 shows the total energies of the heptapeptide fragment in different conformers, in $\mathrm{kcal} / \mathrm{mol}$. Table 4 shows the energy values obtained for the tetrapeptide. The pentapeptide, $\mathrm{Glu}^{20}-\mathrm{Asp}^{21}-\mathrm{Phe}^{22}-\mathrm{Val}^{23}-\mathrm{Lys}^{24}$, was optimized with the use of the 3-21G basis set in an extended conformation and in a cyclic conformation allowing hydrogen bonding between glutamic acid and lysine. The hydrogen bonds are between the carboxyl hydrogen and the lone pair of electrons on the $\varepsilon$-amino group of lysine. Single-point energies using the 3-21G obtained geometries were calculated using the $6-31 G^{*}$ basis set. The energy values are shown in Table 5. The optimized structures are shown in Figure 5.

\section{Results and Discussion}

We prepared glucagon analogs with intramolecular side chain lactams by solid-phase peptide synthesis using a Boc strategy (24). Internal lactams were designed at three different locations: at the $\mathrm{N}$-terminal portion of the molecule between positions 2 and analog 2, close to the central hinge region between positions 9 and 12, analogs 3 and 4 , and at the C-terminal end of the molecule between positions 20 and 24, analog 5. Lactam formation occurred between a $\mathrm{COOH}$ side chain provided by a glutamic
Table 2. Geometry of complexes 1 and 2 ( $X$ and degree)

Bond Lengths

\begin{tabular}{|c|c|c|c|c|}
\hline & la & $1 b$ & $2 a$ & $2 b$ \\
\hline $\mathrm{Nl-H1}$ & 1.874 & - & 1.905 & - \\
\hline $\mathrm{Hl}-\mathrm{Ol}^{\prime}$ & - & 1.601 & - & 1.579 \\
\hline $\mathrm{H} 2-\mathrm{O} 2^{\prime}$ & - & 2.000 & - & 1.924 \\
\hline NlCl & 1.467 & 1.488 & 1.465 & 1.481 \\
\hline $\mathrm{C} 1 \mathrm{C} 2$ & 1.525 & 1.524 & 1.524 & 1.524 \\
\hline $\mathrm{C} 2 \mathrm{C} 3$ & 1.531 & 1.533 & 1.530 & 1.531 \\
\hline $\mathrm{C} 3 \mathrm{C} 4$ & 1.533 & 1.532 & 1.533 & 1.529 \\
\hline $\mathrm{C} 4 \mathrm{C} 5$ & 1.537 & 1.533 & 1.537 & 1.530 \\
\hline $\mathrm{C} 5 \mathrm{C} 6$ & 1.516 & 1.520 & 1.516 & 1.506 \\
\hline C5N2 & 1.455 & 1.455 & 1.455 & 1.454 \\
\hline $\mathrm{C} 6 \mathrm{Ol}$ & 1.186 & 1.187 & 1.191 & 1.158 \\
\hline C5H5 & 1.088 & 1.094 & 1.088 & 1.091 \\
\hline $\mathrm{Hl}^{\prime} \mathrm{Ol}^{\prime}$ & 0.975 & - & 0.973 & - \\
\hline $\mathrm{Ol}^{\prime} \mathrm{Cl} \mathrm{l}^{\prime}$ & 1.314 & 1.235 & 1.315 & 1.252 \\
\hline $\mathrm{O} 2^{\prime} \mathrm{Cl}^{\prime}$ & 1.198 & 1.255 & 1.195 & 1.252 \\
\hline $\mathrm{Cl}^{\prime} \mathrm{C} 2^{\prime}$ & 1.512 & 1.525 & 1.510 & 1.523 \\
\hline $\mathrm{C} 2^{\prime} \mathrm{C} 3^{\prime}$ & 1.529 & 1.543 & 1.525 & 1.529 \\
\hline $\mathrm{C} 3^{\prime} \mathrm{C} 4^{\prime}$ & 1.525 & 1.520 & 1.531 & 1.564 \\
\hline $\mathrm{C}^{\prime} \mathrm{O} 3^{\prime}$ & 1.182 & 1.192 & - & - \\
\hline $\mathrm{C}^{\prime} \mathrm{Nl}^{\prime}$ & 1.447 & 1.446 & - & - \\
\hline $\mathrm{C}^{\prime} \mathrm{H}^{\prime}$ & 1.091 & 1.092 & - & - \\
\hline $\mathrm{C} 4^{\prime} \mathrm{N} 1^{\prime}$ & - & - & 1.448 & 1.453 \\
\hline $\mathrm{C}^{\prime} \mathrm{C} 5^{\prime}$ & - & - & 1.523 & 1.511 \\
\hline $\mathrm{C}^{\prime} \mathrm{O}^{\prime}$ & - & - & 1.188 & 1.188 \\
\hline $\mathrm{C} 4^{\prime} \mathrm{H} 4^{\prime}$ & - & - & 1.094 & 1.090 \\
\hline $\mathrm{C5}^{\prime} \mathrm{H}^{\prime}$ & - & - & 1.092 & 1.095 \\
\hline
\end{tabular}

Bond Angles

\begin{tabular}{lcccc}
\hline & $1 \mathrm{a}$ & $1 \mathrm{~b}$ & $2 \mathrm{a}$ & $2 \mathrm{~b}$ \\
$\mathrm{O} 1^{\prime} \mathrm{H} 1^{\prime} \mathrm{N} 1$ & 174.56 & - & 173.23 & - \\
$\mathrm{O} 1^{\prime} \mathrm{H} 1 \mathrm{~N} 1$ & - & 155.48 & - & 157.07 \\
$\mathrm{O} 2^{\prime} \mathrm{H} 2 \mathrm{~N} 1$ & - & 123.12 & - & 128.23 \\
$\mathrm{~N} 1 \mathrm{C} 1 \mathrm{C} 2$ & 110.60 & 111.47 & 110.52 & 110.19 \\
$\mathrm{C} 1 \mathrm{C} 2 \mathrm{C} 3$ & 112.93 & 114.42 & 112.69 & 113.84 \\
$\mathrm{C} 2 \mathrm{C} 3 \mathrm{C} 4$ & 111.79 & 111.48 & 111.60 & 112.27 \\
$\mathrm{C} 3 \mathrm{C} 4 \mathrm{C} 5$ & 115.85 & 114.92 & 116.06 & 114.70 \\
$\mathrm{C} 4 \mathrm{C} 5 \mathrm{C} 6$ & 111.09 & 112.05 & 111.60 & 112.13 \\
$\mathrm{C} 5 \mathrm{C} 6 \mathrm{O} 1$ & 123.54 & 123.91 & 123.20 & 123.58 \\
$\mathrm{C} 4 \mathrm{C} 5 \mathrm{~N} 2$ & 110.07 & 111.43 & 110.53 & 111.91 \\
$\mathrm{H} 1^{\prime} \mathrm{O} 1^{\prime} \mathrm{C} 1^{\prime}$ & 110.67 & - & 110.35 & - \\
$\mathrm{O} 1^{\prime} \mathrm{Cl} 1^{\prime} \mathrm{C} 2$ & 112.19 & 117.23 & 112.70 & 116.9 \\
$\mathrm{H} 101^{\prime} \mathrm{Cl}$ & - & 102.90 & - & 102.74 \\
$\mathrm{H} 2 \mathrm{O} 2^{\prime} \mathrm{C} 1^{\prime}$ & - & 108.11 & - & 107.79 \\
$\mathrm{Cl}^{\prime} \mathrm{C} 2^{\prime} \mathrm{C} 3$ & 114.03 & 109.44 & 112.17 & 112.83
\end{tabular}




\begin{tabular}{|c|c|c|c|c|}
\hline $\mathrm{C} 2^{\prime} \mathrm{C} 3^{\prime} \mathrm{C} 4^{\prime}$ & 111.89 & 110.08 & 112.82 & 112.85 \\
\hline $\mathrm{C}^{\prime} \mathrm{C} 4^{\prime} \mathrm{C} 5^{\prime}$ & - & - & 110.70 & 111.88 \\
\hline $\mathrm{C} 2^{\prime} \mathrm{C} 3^{\prime} \mathrm{Nl}^{\prime}$ & 111.89 & 110.99 & - & - \\
\hline $\mathrm{C}^{\prime} \mathrm{C}^{\prime} \mathrm{O} 3^{\prime}$ & 123.45 & 123.47 & - & - \\
\hline $\mathrm{C} 3^{\prime} \mathrm{C} 4^{\prime} \mathrm{N1}{ }^{\prime}$ & - & - & 111.36 & 107.17 \\
\hline $\mathrm{C}^{\prime} \mathrm{C}^{\prime} \mathrm{O} 3^{\prime}$ & - & - & 123.38 & 124.77 \\
\hline \multicolumn{5}{|c|}{ Dihedral Angles } \\
\hline & la & $1 b$ & $2 \mathrm{a}$ & $2 b$ \\
\hline $\mathrm{Cl}^{\prime} \mathrm{Ol} l^{\prime} \mathrm{Hl}^{\prime} \mathrm{Nl}^{\prime}$ & -125.13 & - & -174.78 & - \\
\hline $\mathrm{Hl}^{\prime} \mathrm{N} 1 \mathrm{ClC} 2$ & -57.80 & - & 64.07 & - \\
\hline $\mathrm{N} 1 \mathrm{ClC} 2 \mathrm{C} 3$ & -171.44 & -57.19 & -175.88 & -57.68 \\
\hline $\mathrm{C} 1 \mathrm{C} 2 \mathrm{C} 3 \mathrm{C} 4$ & -171.86 & -171.05 & -171.02 & -175.22 \\
\hline $\mathrm{C} 2 \mathrm{C} 3 \mathrm{C} 4 \mathrm{C} 5$ & -164.96 & -170.46 & -168.36 & -170.69 \\
\hline C3C4C5N2 & 64.46 & 60.71 & 64.04 & 60.50 \\
\hline C3C4C5C6 & -57.05 & -60.80 & -55.40 & -61.14 \\
\hline $\mathrm{O} 1 \mathrm{C} 6 \mathrm{C} 5 \mathrm{C} 4$ & -105.96 & -36.14 & -110.99 & -36.14 \\
\hline $\mathrm{Ol}^{\prime} \mathrm{Cl} 1^{\prime} \mathrm{C} 2^{\prime} \mathrm{C} 3^{\prime}$ & 173.50 & 88.73 & 168.60 & -124.74 \\
\hline $\mathrm{Cl}^{\prime} \mathrm{C} 2^{\prime} \mathrm{C} 3^{\prime} \mathrm{C}_{4}^{\prime}$ & -62.28 & -55.99 & 178.51 & -174.62 \\
\hline $\mathrm{Cl}^{\prime} \mathrm{C} 2^{\prime} \mathrm{C} 3^{\prime} \mathrm{Nl}^{\prime}$ & 66.80 & 70.98 & - & - \\
\hline $\mathrm{C} 2^{\prime} \mathrm{C}^{\prime} \mathrm{C}^{\prime} \mathrm{O} 3^{\prime}$ & -105.96 & 125.21 & - & - \\
\hline $\mathrm{C} 2^{\prime} \mathrm{C}^{\prime} \mathrm{C} 4^{\prime} \mathrm{Nl}^{\prime}$ & - & - & -67.04 & -151.19 \\
\hline $\mathrm{C} 2^{\prime} \mathrm{C} 3^{\prime} \mathrm{C} 4^{\prime} \mathrm{C} 5^{\prime}$ & - & - & 165.86 & 82.78 \\
\hline $\mathrm{C}^{\prime} \mathrm{C}^{\prime} \mathrm{C}^{\prime} \mathrm{O}_{3}^{\prime}$ & - & - & 141.56 & 119.78 \\
\hline
\end{tabular}

acid residue and an $\mathrm{NH}_{2}$ side chain supplied by a lysine residue at those positions. With this strategy, we aimed to probe for that portion of glucagon that can be stabilized by lactam cyclization formed by an amide bond between the $\gamma$-carboxyl group of a glutamic acid and the $\varepsilon$-amino group of a lysine. In the case of cyclic[Glu ${ }^{2}$ Lys $\left.^{5}\right]$, cyclic $\left[\mathrm{Glu}^{9}\right.$ Lys $^{12}$ ], and

Table 3. Energies (au), binding energy ( $\mathrm{kcal} / \mathrm{mol})$ of complexes 1 and 2

\begin{tabular}{|c|c|c|}
\hline \multicolumn{3}{|c|}{ Complex } \\
\hline \multicolumn{2}{|c|}{ Aspartic-Lysine complex (la) } & -853.69864 \\
\hline \multicolumn{2}{|c|}{ Aspartate ion-lysine ion (lb) } & -853.68014 \\
\hline \multicolumn{2}{|c|}{ Glutamic-lysine complex (2a) } & -892.73339 \\
\hline \multicolumn{2}{|c|}{ Glutamate ion-lysine ion (2b) } & -892.70054 \\
\hline Complex & $\begin{array}{l}\text { Binding } \\
\text { energy }\end{array}$ & $\begin{array}{l}\text { Binding energy }+ \\
\text { Solvation energy }\end{array}$ \\
\hline la & -13.6 & -25.4 \\
\hline lb : vs. ions & -121.2 & -7.0 \\
\hline lb : vs. neutral species & -2.0 & -13.7 \\
\hline $2 \mathrm{a}$ & -12.9 & -24.4 \\
\hline $2 \mathrm{~b}:$ vs. ions & -119.9 & -4.6 \\
\hline $2 \mathrm{~b}$ : vs. neutral species & -4.0 & -13.4 \\
\hline
\end{tabular}<smiles>NCCCCC(N)C(=O)C([Ge])C(N)C=O</smiles>

Lys - Glu

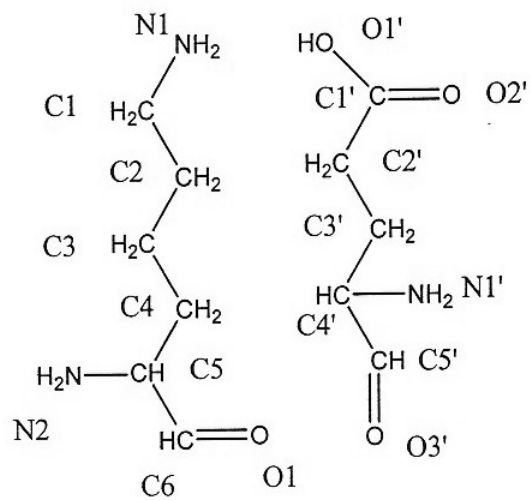

desHis ${ }^{1}$ cyclic [Glu ${ }^{9}$ Lys $^{12}$ ]glucagon amide, analogs 2 , 3, and 4 (Table 1), the oppositely charged side chains were positioned at $i$ and $i+3$ relative to each other. In the cyclic $\left[\mathrm{Glu}^{20} \mathrm{Lys}^{24}\right]$ derivative, analog 5 (Table 1) the charged residues were situated $i$ and $i+4$ relative to each other. Substitution of glutamic acid for aspartic acid at position 9 of glucagon had been shown previously to result in an analog that behaved as a glucagon antagonist (17). The effect of intramolecular lactam formation on receptor binding affinity and subsequent stimulation of adenylyl cyclase was measured. Binding affinity and adenylyl cyclase activity were assayed on rat liver membranes that are

Table 4. Energies of some conformations of the heptapeptidic fragment of glucagon: Thr7-Ser8-asp9tyr10-ser11-lys 12-tyr13 (kcal/mol)

\begin{tabular}{llc}
\hline Structure & Energy & Energy + Solvation Energy \\
\hline $3 \mathrm{a}$ & -538.62 & -572.25 \\
$3 \mathrm{~b}$ & -573.49 & -611.02 \\
$3 \mathrm{c}$ & -539.49 & -571.42 \\
$3 \mathrm{~d}$ & -576.35 & -611.30 \\
\hline
\end{tabular}


Table 5. Energies (au) of the tetrapeptidic fragment of glucagon Asp-Tyr-Ser-Lys as calculated with ab initio calculations, using 3-21G and 6-31G*//3-21G basis sets

\begin{tabular}{|c|c|c|c|c|c|}
\hline & $3-21 G$ & $6-31 G * / / 3-21 G$ \\
\hline \multicolumn{4}{|c|}{ 4a (containing Asp-Lys bridge) } & -1713.92181 & -1723.48502 \\
\hline \multicolumn{4}{|c|}{ 4b (extended) } & -1713.88362 & -1723.44827 \\
\hline \multicolumn{4}{|c|}{ 4c (containing a Lys-backbone $\mathrm{H}$ bond) } & -1713.93222 & -1723.47322 \\
\hline \multicolumn{6}{|c|}{ Energies (kcal/mol) } \\
\hline \multicolumn{2}{|c|}{ Solvation: } & $\begin{array}{c}\text { Relative: } \\
\Delta \mathrm{E}(3-2 \mathrm{IG})\end{array}$ & $\Delta \mathrm{E}(3$ & + Solvation energy & $\Delta \mathrm{E}(6-31 \mathrm{G} * / / 3-21 \mathrm{G})$ \\
\hline $4 a$ & -60.48 & 6.53 & & -53.95 & 0.0 \\
\hline $4 b$ & -29.97 & 30.49 & & .52 & 23.06 \\
\hline $4 \mathrm{c}$ & -44.10 & 0.0 & & -44.10 & 7.41 \\
\hline
\end{tabular}

rich in glucagon receptors. The binding and activity parameters of the glucagon lactams were compared to those of their acyclic counterparts. The cyclic analogs were designed to indirectly provide insight on the importance of internal ion pair formation to glucagon binding and activity. Information from these studies might point to new directions in the design of novel glucagon antagonists.

In addition to synthetic analogs, theoretical calculations were performed on model cyclic peptides based on sequences from glucagon. The energetics of intramolecular hydrogen bond formation within a tetrapeptide, and a heptapeptide, containing an aspartic/glutamic acid at position $i$ and a lysine at the $i+3$ position, and a peptapeptide with a glutamic acid at the $i$ position and a lysine at the $i+4$ position, were calculated using the AMI semi-empirical method for the heptapeptide and the ab initio method using the 3-21G basis set and the 6-31G* basis set for the tetrapeptide and pentapeptide. The tetrapeptide Asp-Tyr-Ser-Lys represented residues 9-12 of glucagon, the heptapeptide Thr-Ser-AspTyr-Ser-Lys-Tyr represented residues 7-14, and the pentapeptide Glu-Asp-Phe-Val-Lys represented residues 20-24. Internal hydrogen bonding between the carboxylic group and amino functional groups of the peptides resulted in a 17-membered cyclic peptide in the case of the $i$ and $i+3$ cyclization (Figs. 3A and $4 \mathrm{~A})$ and a 21 -membered cyclic peptide in the i and $i+4$ cyclization (Fig. 5A). The peptide models mimicked the cyclic glucagon analogs listed in Table 1 . The minimum energies obtained were contrasted with the biological data.

Analog 3, cyclic [Glu ${ }^{9}$ Lys $^{12}$ ]amide, displayed a 20 -fold decrease in binding affinity to $4.8 \%$ and retained weak agonist activity. The acyclic counterpart

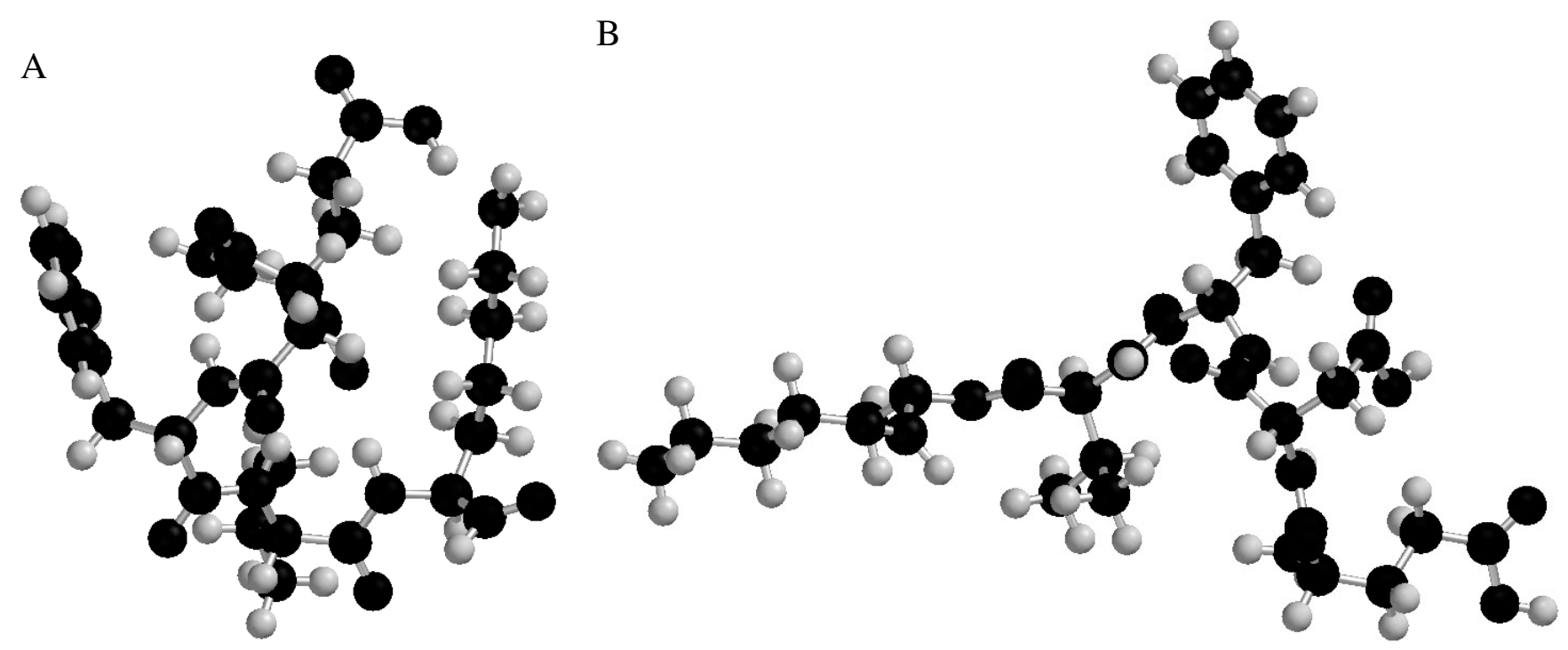

Fig. 5. (A) A cyclic conformation of Glu-Asp-Phe-Val-Lys that features a hydrogen bond between the glutamic and lysine residues. (B) An extended conformation of Glu-Asp-Phe-Val-Lys. 
had a binding affinity of $14 \%$ (17). Deleting histidine 1 in desHis ${ }^{1}$ cyclic $\left[\right.$ Glu $^{9}$ Lys $^{12}$ ]amide, analog 4, abolished the ability to activate adenylyl cyclase even at the highest concentration tested, but the binding affinity was enhanced to $12.6 \%$. Lactam formation between Glu $^{20}$ and $\mathrm{Lys}^{24}$ in desHis ${ }^{1} \mathrm{Glu}^{9-}$ cyclic [Glu ${ }^{20} \mathrm{Lys}^{24}$ ]amide, analog 5 , preserved $20 \%$ binding affinity for glucagon receptors and the derivative did not activate adenylyl cyclase. Not surprisingly, both analogs 4 and 5 were able to inhibit glucagon-stimulated adenylyl cyclase activation and behaved as glucagon antagonists with a comparable $\mathrm{pA}_{2}$ value of 6.8. In contrast, cyclic peptide formation between $\mathrm{Glu}^{2}$ and $\mathrm{Lys}^{5}$ in cyclic $\left[\mathrm{Glu}^{2} \mathrm{Lys} \mathrm{s}^{5}\right]-$ amide, analog 2, was not well-tolerated and resulted in a $99 \%$ loss in binding affinity (Table 1). However, cyclic[Glu ${ }^{2}$ Lys $^{5}$ ]amide was still a full agonist, although with significantly reduced potency.

We have established the critical importance of Asp ${ }^{9}$ glucagon for the activation of the glucagon receptor (5). Moreover, we and others have shown that the positive charge of Lys ${ }^{12}$ contributes both to the binding affinity and to the potency of activation $(9,25)$. The data cannot specify, however, whether these charged residues interact with each other in an intramolecular salt bridge or whether these observations support ion pairing with oppositely charged residues in the receptor binding pocket. Interestingly, because the aspartic acid at position 9 and lysine at position 12 were not altered in cyclic $\left[\mathrm{Glu}^{2} \mathrm{Lys}^{5}\right]$ amide, the analog retained full agonist activity.

What is evident from the bioassay data is that the ligand receptor interface can accommodate a cyclic structure at the C-terminal half but less so at both the midsection of the molecule and close to the $\mathrm{N}$-terminus. The C-terminal half has been shown to be largely helical, while the $\mathrm{N}$-terminus has a more flexible conformation $(26,28)$. The lactam between $\mathrm{Glu}^{2}$ and $\mathrm{Lys}^{5}$ in cyclic[Glu $\left.{ }^{2} \mathrm{Lys}^{5}\right]$ amide, analog 2, restricts chain flexibility and prevents efficient contact with the receptor. However, Asp $^{9}$ in cyclic$\left[\mathrm{Glu}^{2}\right.$ Lys $\left.^{5}\right]$ amide maintained its ability to bring about full activation. Despite the notion that the Nterminal half is mostly responsible for activation and the C-terminal half for binding to the receptor, our results suggest that the first five residues of glucagon are critical for binding.

Lactam cyclization at the midsection of the peptide also impaired receptor binding. Cyclic
[Glu ${ }^{9}$ Lys $^{12}$ ]amide, analog 3, showed only $5 \%$ binding affinity but deletion of histidine in desHis ${ }^{1-}$ cyclic $\left[\mathrm{Glu}^{9} \mathrm{Lys}^{12}\right.$ ]amide, analog 4, restored binding affinity to $13 \%$. The acyclic derivatives [Glu' ${ }^{9}$ glucagon amide and desHis ${ }^{1}\left[\mathrm{Glu}^{9}\right]$ glucagon amide had binding affinities of $14 \%$ and $41 \%$, respectively. These results are consistent with a report that cyclic[Asp ${ }^{9}$ Lys ${ }^{12}$ ]glucagon amide displayed only $1 \%$ binding affinity and was inactive (14) and reinforce the notion that $\mathrm{Asp}^{9}$ and Lys ${ }^{12}$ are not likely to be involved in an intramolecular salt bridge.

A lactam between $\mathrm{Glu}^{20}$ and $\mathrm{Lys}^{24}$ at the C-terminal region of DesHis ${ }^{1}$ Glu $^{9}$ cyclic $\left[\mathrm{Glu}^{20} \mathrm{Lys}^{24}\right.$ ]amide, ana$\log 5$, was better tolerated and the peptide retained $20 \%$ binding affinity. The C-terminal end of the glucagon molecule is largely helical and studies have suggested that helical content is enhanced by conformational constraints such as a lactam bridge. In this analog the connecting side chains are at the $i$ and $i+4$ positions, which has a stabilizing effect on a helix. The lactam in analog 5 is a 21 -membered ring. Formation of a lactam bridge between a Lys ${ }^{17} i$ and a Glu $^{21} \mathrm{i}+4$ was recently shown to be favorable and further supports our finding (29). The lactams in cyclic $\left[\mathrm{Glu}^{2} \mathrm{Lys}^{5}\right]$ amide and cyclic $\left[\mathrm{Glu}^{9} \mathrm{Lys}^{12}\right.$ ]amide, analogs 2 and 3, are more constricted because the connecting side chains are at the $i$ and $i+3$ positions. The lactam in these analogs is an 18 -membered ring that might distort the backbone rather than stabilize it.

Binding energies of the model peptides were calculated as the difference between the energy of the complex and the sum of the energies of the subsystems. As shown in Table 6, the binding energies of aspartic acid and lysine (complex 1) and of glutamic acid and lysine (complex 2) are substantial. Complex la, which features a hydrogen bond between the two neutral species, is slightly more bound than the complex 2 a showing that replacing the aspartic acid residue by a glutamic acid does not influence the binding energy significantly. The same is true of complexes $1 \mathrm{~b}$ and $2 \mathrm{~b}$, which feature the bond between two opposite charges, the aspartate or glutamate anions, respectively, with the lysine cation. In these complexes, two of the lysine $\mathrm{NH}_{3}{ }^{+}$group are bound to the two oxygens of the carboxylate anion. This bond, compared to the separate ions, is very strong due to the electrostatic attraction upon its formation. However, when compared to the

Table 6. Energies (au) of the pentapeptide Glu-Asp-Phe-Val-Lys, relative and solvation energy

\begin{tabular}{lccccc}
\hline & Energy (3-21G) & $\Delta \mathrm{E}(3-21 G)$ & $\begin{array}{c}(\mathrm{kcal} / \mathrm{mol}) \\
\text { Energy(6-31G*) }\end{array}$ & $\Delta \mathrm{E}\left(6-31 \mathbf{G}^{*}\right)$ & Solvation Energy \\
\hline Cyclic & -2112.56024 & 0.0 & -2124.34392 & 0.0 & -51.89 \\
Extended & -2112.54067 & 12.28 & -2124.33707 & 4.30 & -21.66 \\
\hline
\end{tabular}


independent neutral species, it is weaker than the bond in the la and 2 a complexes. Taking into consideration the solvation energies did not influence the trend.

In previous studies, we investigated possible reasons for the loss of activity of the glucagon analog with $\mathrm{Asp}^{9}$ to $\mathrm{Glu}^{9}$ substitution. It was reasoned that shifting the carboxyl position affects the topographic interaction of $\mathrm{Asp}^{9}$ with a critical contact point in the receptor that switches on the activation response (30). According to the results in Table 2, the stabilization energy of salt bridge formation between aspartic acid and lysine would not be measurably different if aspartic acid were replaced with a glutamic acid. Thus, the addition of one methylene group in glutamic acid would not be a contributing factor to the loss in activity if aspartic acid were involved in an intramolecular salt bridge.

Table 3 shows that at AMI calculational level, the extended species of the heptapeptide Thr-SerAsp-Tyr-Ser-Lys-Tyr, which represents the 7-13 fragment of glucagon, is more stable than the cyclic model, with or without the inclusion of the solvation energy. However, as shown in Table 4, salt bridge formation between Asp and Lys of the $(i+3)$ tetrapeptide Asp-Tyr-Ser-Lys, resulted in a cyclic conformation that had a lower energy than the extended tetrapeptide Asp-Tyr-Ser-Lys, at both 3-21G and $6-31 G^{*} / / 3-21 G$ levels. This peptide fragment represents residues 9-12 of glucagon. The same system investigated at AMI level shows the extended conformation as more stable, indicating that AMI calculations are not appropriate for the description of these systems. This is probably due to a poor description of hydrogen bonds.

As seen in Table 4, at 3-21G calculational level, the energy of the structure $4 \mathrm{c}$, which features a hydrogen bond between a backbone oxygen and one of the hydrogens on the $\varepsilon$-amino nitrogen, is lower than the one of the structure $4 a$, which features the Asp $^{9}$-Lys ${ }^{12}$ hydrogen bond in which the hydrogen is positioned on the carboxyl as in Figure 1A or 2A. However, when the solvation energy is taken into consideration, the order is reversed, which suggests that the Asp ${ }^{9-}$ Lys $^{12}$ salt bridge is less likely to form in a hydrophobic pocket. This observation is consistent with the idea that the peptide ligand binds very close to the lipid bilayer and is most likely stabilized by hydrophobic interactions with the membranebound receptor protein. At 6-31G*//3-21G calculational level, 4a is the lowest in energy, even without solvation energy added.

A peptide lactam desHis ${ }^{1}$ cyclic $\left[\mathrm{Glu}^{9} \mathrm{Lys}^{12}\right]$-amide produced from an i to $i+3$ cyclization of a $\gamma-\mathrm{COOH}$ and $\varepsilon$-amino of $\mathrm{Glu}^{9}$ and $\mathrm{Lys}^{12}$, respectively, was shown to have a lower binding affinity than its acyclic counterpart, which was reported to have a binding affinity of $41 \%$ (17). This observation supports the notion that the Glu9 carboxyl and the Lys ${ }^{12}$ amino groups are not likely to interact intramolecularly, but may instead engage in ionic interactions with receptor protein residues (Table 1 ). The $\mathrm{Glu}^{9}$ derivative is uncoupled from the receptor, and thus, the decreased binding may be due to the loss of the Lys ${ }^{12}$ interaction. These results are consistent with the finding that cyclic $\left[\right.$ Asp $^{9}$ Lys $^{12}$ ] glucagon amide retained only $1 \%$ binding affinity and was inactive (14).

An amide bond between $\gamma$ - $\mathrm{COOH}$ and $\varepsilon$-amino of $\mathrm{Glu}^{20}$ and $\mathrm{Lys}^{24}$, respectively, was tolerated in the analog DesHis ${ }^{1}$ Glu $^{9}$ cyclic $\left[\mathrm{Glu}^{20} \mathrm{Lys}^{24}\right.$ ]amide and $20 \%$ binding affinity was retained. As seen in Table 5, a pentapeptide Glu-Asp-Phe-Val-Lys, which represents the 20-24 segment of a glucagon analog, exhibited a lower energy for the cyclic conformation involving an Asp/Lys salt bridge than for the extended one using ab initio calculations, HartreeFock, with the 3-21G basis set. The pentapeptide is more stable in the cyclic form than the extended form by $12.28 \mathrm{kcal}$ and also exhibits a stronger solvation energy (Table 5). In the tetrapeptide the cyclic conformation containing the salt bridge in Figure $4 \mathrm{~A}$ is more stable than the extended form in Figure 4B by about $23 \mathrm{kcal} / \mathrm{mol}$, but its solvation energy is much higher, making it much more stable. As seen in Tables 4 and 5, both with and without taking into account the solvation energy, the cyclic tetrapeptide shows a greater stabilization compared to the extended form than does the cyclic pentapeptide.

Our results are consistent with tentative models that have been proposed for the binding of peptide ligands to members of family B-type GPCRs $(31,32)$. In this model, binding of the peptide ligand to its receptor occurs in two steps. First, a helical conformation is induced as the peptide associates nonspecifically with the membrane bilayer, followed by a second conformational change when the $\mathrm{N}$-terminus of the peptide interacts with the membrane-bound receptor and activates it. The Cterminal end of the glucagon molecule has been shown by $\mathrm{x}$-ray structure analysis to be largely helical (26). The current model indicates that this structure may closely represent the physiologic conformation of glucagon in the presence of its membrane-bound receptor, contrary to earlier assumptions.

In summary, data obtained from our cyclic glucagon analogs support a current model of the active conformation of glucagon. The peptide ligand in solution can assume many conformations. A small population of these conformations will predominate when the ligand interacts with its receptor on the cell surface. We tested the idea that an internal salt bridge might contribute to the stabilization of this putative conformation. Biological data bolstered by ab initio calculations indeed show good probability that an intramolecular salt bridge at the C-terminus of glucagon might facilitate provide local stabilization within the peptide as it interacts with its receptor. In contrast, an intramolecular salt bridge has a destabilizing effect at the $\mathrm{N}$-terminal $\mathrm{l}-13$ sequence 
that contains residues required for interaction with the receptor. Thus, an internal i to $\mathrm{i}+4$ intramolecular salt bridge at the C-terminal half of glucagon may be a useful feature in antagonist design and may lead to novel glucagon antagonists.

\section{Acknowledgment}

This work was supported by U. S. Public Health Service Grant DK24039.

\section{References}

1. Unger RH, Orci L. (1981) Glucagon and the A cell: physiology and pathophysiology (first two parts). N. Engl. J. Med 304: 1518-1524.

2. Dobbs R, Sakurai H, Sasaki H, et al. (1975) Glucagon: role in the hyperglycemia of diabetes mellitus. Science 187: 544547.

3. Jelinek LJ, Lok S, Rosenberg GB, et al. (1993) Expression cloning and signaling properties of the rat glucagon receptor. Science 259: 1614-1616.

4. Ulrich CD, Holtmann M, Miller LJ. (1998) Secretin and vasoactive intestinal peptidereceptors: members of a unique family of G protein-coupled receptors. Gastroenterology 114: 382-397.

5. Unson CG, Macdonald D, Ray K, Durrah TL, Merrifield RB.(1991) Position 9 replacement analogues of glucagon uncouple biological activity and receptor binding. J. Biol. Chem. 266: 2763-2766.

6. Unson CG, Wu CR, Merrifield RB. (1994) Roles of aspartic acid 15 and 21 in glucagon action: receptor anchor and surrogates for aspartic acid 9. Biochemistry 33: 6884-6887.

7. Lin MC, Wright DE, Hruby VJ, Rodbell M. (1975) Structurefunction relationships in glucagon: properties of highly purified Des-His ${ }^{1}$-monoiodo-, and Des-[ $\left.\mathrm{Asn}^{28} \mathrm{Thr}^{28}\right]$ homoserine lactone glucagon. Biochemistry 14: 1559-1563.

8. Unson CG, Macdonald D, Merrifield RB. (1993) The role of histidine-1 in glucagon action. Arch. Biochem. Biophys. 300: $747-750$

9. Unson CG, Wu CR, Cheung CP, Merrifield RB. (1998) Positively charged residues at positions 12, 17, and 18 of glucagon ensure maximum biological potency. J. Biol. Chem. 273: 10308-10312.

10. Sturm NS, Lin Y, Burley SK, et al. (1998) Structure-function studies on positions 17,18 , and 21 replacement analogues of glucagon: the importance of charged residues and salt bridges in glucagon biological activity. J. Med. Chem. 41: 26932700.

11. Unson CG, Cypess AM, Kim HN, et al. (1995) Characterization of deletion and truncation mutants of the rat glucagon receptor. Seven transmembrane segments are necessary for receptor transport to the plasma membrane and glucagon binding. J. Biol. Chem. 270: 27720-27727.

12. Buggy JJ, Livingston JN, Rabin DU, Yoo-Warren H. (1995) Glucagon.glucagon-like peptide I receptor chimeras reveal domains that determine specificity of glucagon binding. J. Biol. Chem. 270: 7474-7478.
13. Krstenansky JL, Trivedi D, Johnson D, Hruby VJ. (1986) Conformational considerations in the design of a glucagon analogue with increased receptor binding and adenylyl cyclase potencies. J. Am. Chem. Soc. 108: 1696-1698.

14 Trivedi D, Lin Y, Ahn JM, et al. (2000) Design and synthesis of conformationally constrained glucagon analogues. J. Med. Chem. 43: 1714-1722.

15. Mojsov S, Merrifield RB. (1984) An improved synthesis of crystalline mammalian glucagon. Eur. J. Biochem. 145: 601-605.

16. Tam JP, Heath WF, Merrifield RB. (1983) SN2 Deprotection of synthetic peptides with a low concentration of Hf in dimethyl sulfide: evidence and application in peptide synthesis. J. Am. Chem. Soc. 105: 6442-6455.

17. Unson CG, Andreu D, Gurzenda EM, Merrifield RB. (1987) Synthetic peptide antagonists of glucagon. Proc. Natl. Acad. Sci. U.S.A 84: 4083-4087.

18. Pohl SL. (1976) The Glucagon Receptor in Plasma Membranes Prepared from Rat Liver. New York: Dekker; 160-164.

19. Markwell MA, Haas SM, Bieber LL, Tolbert NE. (1978) A modification of the Lowry procedure to simplify protein determination in membrane and lipoprotein samples. Anal. Biochem. 87: 206-210.

20. Wright DE, Rodbell M. (1979) Glucagon 1-6 binds to the glucagon receptor and activates hepatic adenylate cyclase. J. Biol. Chem. 254: 268-269.

21. Salomon Y, Londos C, Rodbell MA. (1974) Highly sensitive adenylyl cyclase assay. Anal. Biochem. 58: 541-548.

22. Arunlakshana O, Schild HO. (1959) Some quantitative uses of drug antagonists. Br. J. Pharmacol. 14: 48-58.

23. Chambers CC, Hawkins GD, Cramer CJ, Truhlar DG. (1996) Model for aqueous solvation based on class IV atomic charges and first-solvation shell effects. J. Chem. Phys. 100: 16385.

24. Merrifield RB. (1963) Solid phase peptide synthesis. J. Am. Chem. Soc. 85: 2149-2 154.

25. Carrey EA, Epand RM. (1982) The role of nonspecific hydrophobic interactions in the biological activity of $\mathrm{N}^{\mathrm{e}}$-acyl derivatives of glucagon. J. Biol. Chem. 257: 10624-10630.

26. Sasaki K, Dockerill S, Adamiak DA, Tickle IJ, Blundell T. (1975) X-ray analysis of glucagon and its relationship to receptor binding. Nature 257: 75 1-757.

27. Korn AP, Ottensmeyer FP. (1983) A model for the threedimensional structure of glucagon. J. Theor. Biol. 105: 403-425.

28. Braun W, Wider G, Lee KH, Wuthrich K. (1983) Conformation of glucagon in a lipid-water interphase by $1 \mathrm{H}$ nuclear magnetic resonance. J. Mol. Biol. 169: 92 1-948.

29. Sapse A, Mezei M, Jain DC, Unson C. (1994) Ab initio study of aspartic and glutamic acid: supplementary evidence for structural requirements at position 9 for glucagon activity. J. Mol. Structure 306: 225-233.

30. Bisello A, Adams AE, Mierke DF, et al. (1998) Parathyroid hormone-receptor interactions identified directly by photocross-linking and molecular modeling studies. J. Biol. Chem. 273: 22498-22505.

31. Hjorth SA, Schwartz TW. (1996) Glucagon and GLP-1 receptors: lessons from chimeric ligands and receptors. Acta Physiol. Scand. 157: 343-345.

32. Inooka H, Ohtaki T, Kitahara O, et al. (2001) Conformation of a peptide ligand bound to its G-protein coupled receptor. Nat. Struct. Biol. 8: 161-165. 